\title{
ENERGY EFFICIENCY IMPROVEMENT IN THE SYSTEM FOR DRYING BAKER'S YEAST
}

\author{
Aleksandar Anastasovski \\ International Balkan University - Skopje, Macedonia \\ AleksandarA@t.mk
}

\begin{abstract}
Drying processes are one of the main consumers of heat energy in production. Any decreases in heat consumption during the drying process will considerably decrease production costs. This study analyzes the high consumption of heat in the drying of baker`s yeast. The main task is to minimize the energy demand and lower the price of the final products with partial heat recovery. These changes will require system modifications. One of the most popular and effective methods that can be used in this case is heat process integration with Pinch Technology. In this study, a reference system was simulated with a mathematical model and analyzed for waste heat streams.

This paper suggests the redesigning of a drying system for production of active dry yeast. Selected streams that satisfy conditions for heat process integration were involved in the evaluation for a better solution. Two different scenarios were proposed as possible solutions. The suggested solutions are retrofit designs of Heat Exchanger Networks. These Heat Exchanger Networks include already installed heat exchangers as well as new heat transfer units. The selection of better design was made with economic analysis of investment. The proposed scenarios of the analyzed sub-system give improvement in heat energy recovery. The best determined solution reduces the cost and thus has the highest profitability, but not the highest heat energy recovery.
\end{abstract}

Keywords: heat integration; retrofit process integration; Pinch Technology; simulation

\section{ПОДОБРУВАЊЕ НА ЕНЕРГЕТСКАТА ЕФИКАСНОСТ ВО СИСТЕМОТ ЗА СУШЕЊЕ НА ПЕКАРСКИОТ КВАСЕЦ}

Процесите на сушење се едни од најголемите потрошувачи на топлинската енергија во производствените постројки. Секоја намалена потрошувачка на топлина во процесот на сушење значително ги намалува производствените трошоци. Оваа студија ја анализира високата потрошувачка на топлинската енергија при сушење на пекарскиот квасец. Главна цел е минимизирање на потребната топлина и намалување на крајната цена на производот со делумен поврат на енергијата во системот. За да се направат овие промени, потребна е модификација на системот. Еден од најчесто користените методи во вакви случаи е постапката за топлинското процесно интегрирање со помош на Пинч-технологијата. Во оваа студија референтниот систем е симулиран врз основа на неговиот математички модел и е анализирано присуството на отпадна топлина.

Овде се претставува можноста за редизајнирање на системот за сушење во производството на сув активен пекарски квасец. Потребно е решенијата да ги содржат процесните струи кои ги задоволуваат основните услови за процесно интегрирање. Предложени се две сценарија како надградба на дизајнот на мрежата од топлински разменувачи. Новите редизајни на мрежите од топлински разменувачи користат нови топлински разменувачи, како и дел од постоечките во самиот систем за сушење. Селекцијата на подоброто решение е направена врз база на економска анализа. Сите предложени решенија го подобруваат враќањето на топлинската енергија во системот. Избраното (најдобро) решение ги намалува производствените трошоци и создава 
највисок профит доколку се инвестира во него. Но, истото тоа решение не ја дава највисоката енергетска ефикасност на системот.

Клучни зборови: топлинска интеграција; процесна надградба; пинч-технологија, симулација

\section{INTRODUCTION}

The dehydration or drying process preserves the vitality of microorganisms as live cells. In the case when those microorganisms are a commercial product, such as baker's yeast, this process extends its shelf-life for a longer time period. The drying process can be done in different conditions, with cooling, heating, hot air, a heated rotating cylinder, a vacuum, etc. However, drying of baker's yeast uses hot dry air. Hot dry air removes water from the drying material. The dynamics of this process can be defined by the dryer type and microorganism's characteristics. Furthermore, drying is a process with a high heat demand. As such, high heat consumption is a common problem in the production of active dry baker's yeast.

This heat demand problem has been reported in the referent production system near the city of Bitola, Macedonia. The main part of the production cost, as well as a great part of the price of the product, depends on drying cost. These costs can be minimized only in circumstances when heat demand is reduced or part of the waste heat is recovered. The main strategy in solving this problem is to redesign the existing process to reuse part of the thermal energy within the system. That process can be completed with use of Pinch Technology for heat Process Integration (PI). The methodology of Pinch Technology is based on heat recovery from streams involved in the process. That means that there should be a system of heat transfer between streams with surplus heat (hot streams) and streams that need to be heated (cold streams) [1]. The analysis of the production process can determine the amount of heat that can be recovered.

The current heat demand in the reference drying facility (data from the company) is approximately $16659 \mathrm{~kJ} / \mathrm{kg}$ dry yeast. This value is because heating requires $12960 \mathrm{~kJ} / \mathrm{kg}$ dry yeast and cooling requires $3699 \mathrm{~kJ} / \mathrm{kg}$. Decreasing these values is possible with the implementation of a heat process integration methodology. Furthermore, such a process will automatically cause a reduction in the cost and thus the price of the product. The difference between the current and new production costs is the profit of heat recovery for the project.
That profit is the income from the investment in such a retrofit design.

This paper shows a case study of one such specific drying process. There are no known resources related to minimizing the heat demand for continuous drying in the production of baker's yeast. Some published articles describe the probability of using of Pinch Technology in food processing, yet never for baker`s yeast. Here, the case study improved the drying process for the living yeast cells.

Many authors show different methodologies to increase energy efficiency. They have used various approaches. Turker et al. [2] made optimization based on a mathematical model of the drying process. They used a few characteristics of yeast and water transport phenomena as selected process parameters in the mathematical model. Mathematical methods are applied to achieve optimal values. Similarly, Akbari et al. [3] described the optimization of drying baker`s yeast in a fluidized bed dryer. Their optimization was conducted through maximizing dry yeast activity (fermentation power) as the main parameter. The maximal yeast activity value is determined as a function of the other involved processing parameters. However, in these conditions, heat demand is not optimized. The heat in this case has the value determined for maximal fermentation power of baker's yeast; this value can vary along with the biochemical properties of the product.

The most effective way of heat recovery is most likely a retrofit design with Pinch Technology. There are many case studies in heat optimization of drying processes. Most of them use heat process integration as their ideal methodology. This methodology has been used in many different types of drying facilities. One of the earliest applications of process integration in dryers is reported by Sebastian et al. [4], who optimized conveyor belt dryers. In the last decade, drying systems are intensively analyzed, projected and redesigned with heat integration. Furthermore, Walmsley et al. [5-7] analyzed the spray drying of milk. In that study, the exhaust gas contained some amount of surplus heat, which heat is used for partial heat recovery. Furthermore, Walmsley et al. [8] redesigned the milk evaporation system based on Pinch 
Technology. In that study, mechanical vapor recompression decreased the use of steam by $78 \%$. The drying process is also part of biogas production from biomass, which has been analyzed previously by Heyne and Harvey [9]. That study used surplus heat energy from selected streams for heat recovery with Pinch Technology. Moreover, Arsenyeva et al. [10] reused sensitive and latent heat energy from exhaust gases in different industrial applications. They determined $\Delta T_{\min }$, confirms the position of the gas-liquid separator and the design of the heat exchanger networks. Some production equipment and machines are already designed to work with higher energy efficiency and have a system for heat recovery. According to Sivill and Ahtila [11], modern machines for paper drying contain a heat recovery system that uses exhaust gases. However, the drying system can be ineffective when process parameters or their values change. In that situation, Sivill et al. [12] analyzed different cases to improve energy efficiency, concluding that changing heat integrated processes influences the heat efficiency. Heat recovery solutions are designed for certain steady state conditions that are related to the reliability of heat exchanger networks as effective solutions for energy efficiency.

Pinch Technology is a heat process integration tool. It is widely used for design or improvement of systems for heat recovery. The production of baker's yeast allows for many opportunities in the process integration of different modes of processes [13]. Batch processes are more complex for analysis than continuous processing. Raskovic et al. [14] reported on the increasing energy efficiency in the baker's yeast industry with the use of heat process integration. This increase in efficiency was based on total site heat integration. Heat integration can sometimes be done between process sections that are physically very far from each other, which would lead to higher heat loss and additional problems. In the current case study, the author maximize heat efficiency within the same subsystem as part of baker's yeast production system. The working mode of a drying sub-system is continuous. Continuous processes have almost constant consumption during the production time. As such, there might be some very small variations in the parameter values.

Energy efficiency can be improved by a combination of different techniques. In the last decade, renewable energy sources and thermodynamic cycles have been used in combination with process integration. Additionally, solar thermal energy is a good source for free heating, yet it can be used only in special regions with good insolation [15]. Similarly, the organic rankine cycle is used in combination with processi techniques [16]. That system works as a heat pump with steam generation for electricity production. Overall, the prior research discussed here provides many ideas for possible solutions. However, in general, pinch technology is the leading technique for solving energy efficiency problems.

\section{SYSTEM SIMULATION AND ANALYSIS}

The potential of a drying subsystem (DS) for heat recovery can be determined with its simulation and heat analysis. Within the DS, many waste streams contain surplus heat. As such, the strategy for process heat integration was planned with the following steps:

- Step 1 - Create a mathematical model of the subsystem based on mass and heat balances

- Step 2 - Generate a system simulation based on a previously established mathematical model (simulation would help to detect and select energy streams for possible process integration).

- Step 3 - Process data extracted from selected streams.

- Step 4 - Conduct Pinch analysis

- Step 5 - Targeting

- Step 6 - Design of heat exchanger networks solutions

- Step 7 - Economic analysis of designed

The description of subsystem was used to better understand the production process. Both the mass and heat balance define the relationship between the involved process streams. This relationship was used to simulate given process conditions. Furthermore, the model was used to validate the parameter values. Next, process streams that satisfy the general principles of Pinch Technology were selected for heat integration. Steps 5 and 6 are basic steps of Pinch Technology [17] and will be explained in chapter 5 of this article. The last step includes profitability analyses and the range of solutions, which can insure the right selection of the suggested final designs.

\section{DESCRIPTION OF DRYING PROCESS}

In general, the drying process for active dry yeast has two different modes: batch or continuous. The better method is still up for debate. The facility for drying baker's yeast works in continuous mode, with a fluidized bed dryer. The scheme of 
drying process with streams and additional equipment is given in Figure 1. Before drying, the yeast must be separated from the yeast cream. The yeast cream is a suspension of live yeast cells in water. The cells are separated from the cream via filtration on a rotary vacuum filter. The yeast is then separated as a solid state with high content of water, containing a maximum $33 \%$ dry matter. Yeast in this solid form enters the fluidized bed dryer as stream 1 . The rest of the water is removed during the drying process. The final product can have a maximum of $97 \%$ dry matter.

The fluidized bed dryer consists of three separate zones (zones 1-3). Every zone has a specific temperature and moisture profile. Fresh yeast that enters the first zone has the highest content of water. There is the highest moisture removal rate in the first zone, where approximately $68 \%$ of the water content is removed. The semi-dried yeast from the first zone continues drying in the second zone. The transfer of particles from the first zone to the second zone depends on the weight of the particles (stream 15) and the height of the wall between zones. The hot dry air enters from the bottom of the zones through the perforated metal sieve. The vertical position of the uniform yeast particles depends on the different content of water and the flow of dry air. Only light particles with a specific content of water can reach a position higher than the wall. All of those particles "jump" the wall and enter in the next drying zone. Stream 15 is a fluidized flow of yeast particles between the first and second zone. The wall that separates the second and third zone works in the same way; stream 16 is therefore also a fluidized flow of yeast particles. The rest of water content (up to $95 \%$ ) is removed in the second and the third zones.

One of the most important fluids for drying process is conditioned dry air. The dry air enters each zone through the metal sieves in the dryer. Air exits are used through the top of the device as wet air. The air outlet has a lower temperature than the temperature in the entrance of each zone. The temperature decline is caused by the endothermic process of water dissolving into the dry air. The inlet temperatures of dry air in every zone are controlled with air heaters. Therefore, streams 17, 18 and 19 are heated with steam and have different process temperatures needed in the drying process for every zone (Table 1).

The air is conditioned in a few steps. The first step to condition environmental air is filtering through air filters. In that step, all impurities, such as solid and dust particles are removed. The filtered air is chilled (CU, Fig. 1) to low temperatures $\left(0{ }^{\circ} \mathrm{C}-9{ }^{\circ} \mathrm{C}\right)$. The surplus moisture condenses at low temperatures. It is separated as liquid water and collected in the cyclone (CY). Then, the relative humidity of the air becomes $100 \%$ (stream 6). After that, the rest of the moisture is adsorbed onto an adsorption layer. The air that exits the adsorption step is the processed dry air (stream 3). A great portion of the processed dry air is used to supply all drying zones (stream 8). The other part (streams 4 and 5) are used in regeneration of the adsorption layer. The system is used for air conditioning, i.e. dehumidification, which is called the Munters station [19].

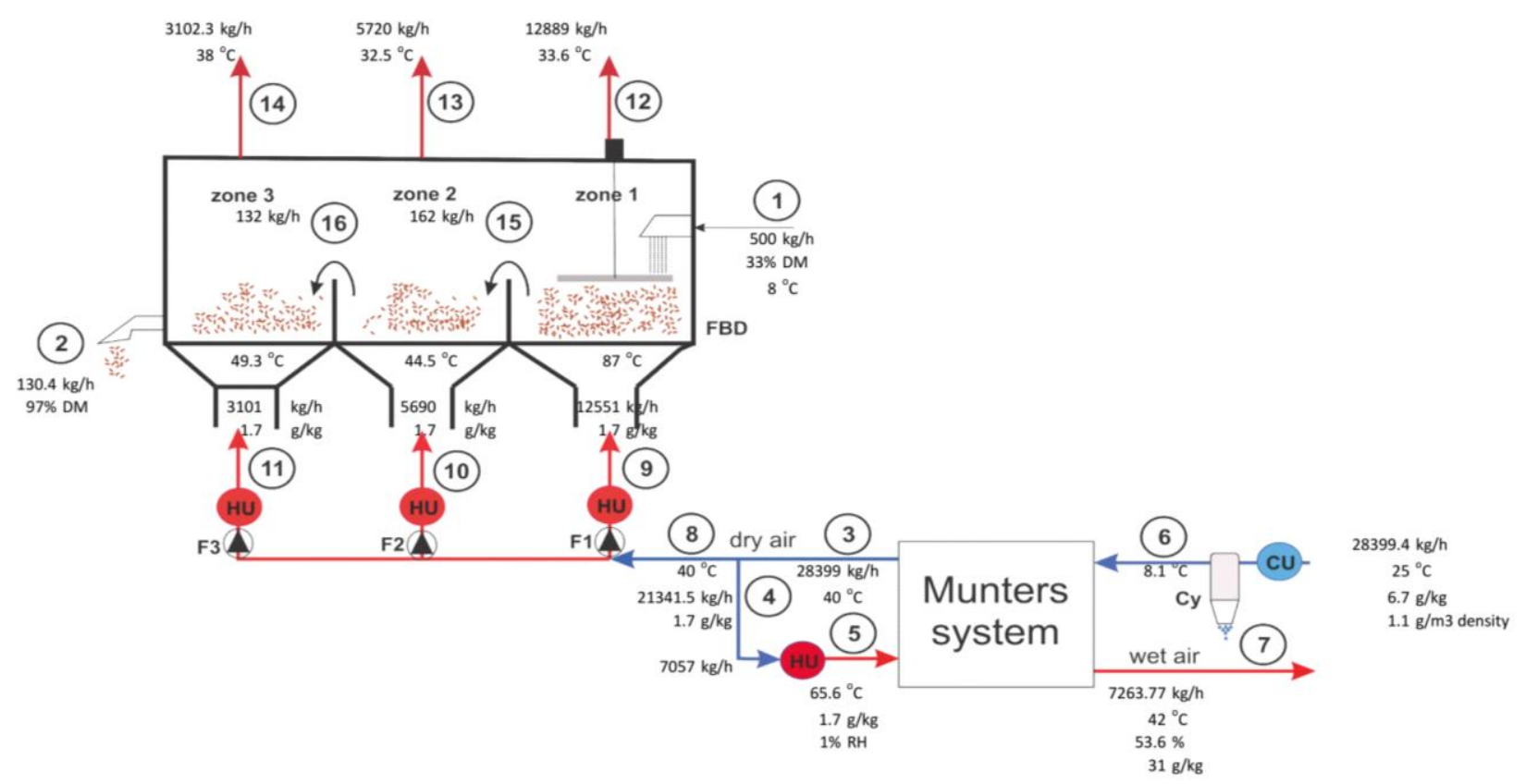

Fig. 1. The Fluidized Bed Drying system - process scheme with mathematical model used in MS Excel 
Table 1

The characteristics of streams in drying process

\begin{tabular}{clcc}
\hline \hline Stream No. & \multicolumn{1}{c}{ Composition } & Flow $[\mathrm{kg} / \mathrm{s}]$ & Temperature $\left[{ }^{\circ} \mathrm{C}\right]$ \\
\hline 1 & Fresh yeast (33 \% dry matter) & 0.139 & 10 \\
2 & Active dry yeast $(97 \%$ dry matter) & 0.0362 & 38 \\
3 & Air (humidity $1.7 \mathrm{~g} \mathrm{H}_{2} \mathrm{O} / \mathrm{kg}$ air) & 7.872 & 40 \\
4 & Air (humidity $1.7 \mathrm{~g} \mathrm{H}_{2} \mathrm{O} / \mathrm{kg}$ air) & 1.921 & 40 \\
5 & Air (humidity $1.7 \mathrm{~g} \mathrm{H}_{2} \mathrm{O} / \mathrm{kg}$ air) & 1.921 & 86.5 \\
6 & Air (humidity $6.7 \mathrm{~g} \mathrm{H}_{2} \mathrm{O} / \mathrm{kg}$ air) & 7.8887 & 8.1 \\
7 & Air (humidity $31.0 \mathrm{~g} \mathrm{H}_{2} \mathrm{O} / \mathrm{kg}$ air) & 1.96 & 61.6 \\
8 & Air (humidity $1.7 \mathrm{~g} \mathrm{H}_{2} \mathrm{O} / \mathrm{kg}$ air) & 5.928 & 40 \\
9 & Air (humidity $1.7 \mathrm{~g} \mathrm{H}_{2} \mathrm{O} / \mathrm{kg}$ air) & 3.486 & 87 \\
10 & Air (humidity $1.7 \mathrm{~g} \mathrm{H}_{2} \mathrm{O} / \mathrm{kg}$ air) & 1.581 & 44.5 \\
11 & Air (humidity $1.7 \mathrm{~g} \mathrm{H}_{2} \mathrm{O} / \mathrm{kg}$ air) & 0.861 & 49.3 \\
12 & Air (humidity $28.6 \mathrm{~g} \mathrm{H}_{2} \mathrm{O} / \mathrm{kg}$ air) & 3.58 & 33.6 \\
13 & Air (humidity $7.0 \mathrm{~g} \mathrm{H}_{2} \mathrm{O} / \mathrm{kg}$ air) & 1.59 & 32.5 \\
14 & Air (humidity $2.3 \mathrm{~g} \mathrm{H}_{2} \mathrm{O} / \mathrm{kg}$ air) & 0.862 & 38 \\
15 & Semi-dry yeast & 0.045 & 36.6 \\
16 & Semi-dry yeast & 0.0367 & 32.5 \\
17 & Air (humidity $1.7 \mathrm{~g} \mathrm{H}_{2} \mathrm{O} / \mathrm{kg}$ air) & 3.486 & 40 \\
18 & Air (humidity $1.7 \mathrm{~g} \mathrm{H}_{2} \mathrm{O} / \mathrm{kg}$ air) & 1.581 & 40 \\
19 & Air (humidity $1.7 \mathrm{~g} \mathrm{H}_{2} \mathrm{O} / \mathrm{kg}$ air) & 0.861 & 40 \\
\hline \hline
\end{tabular}
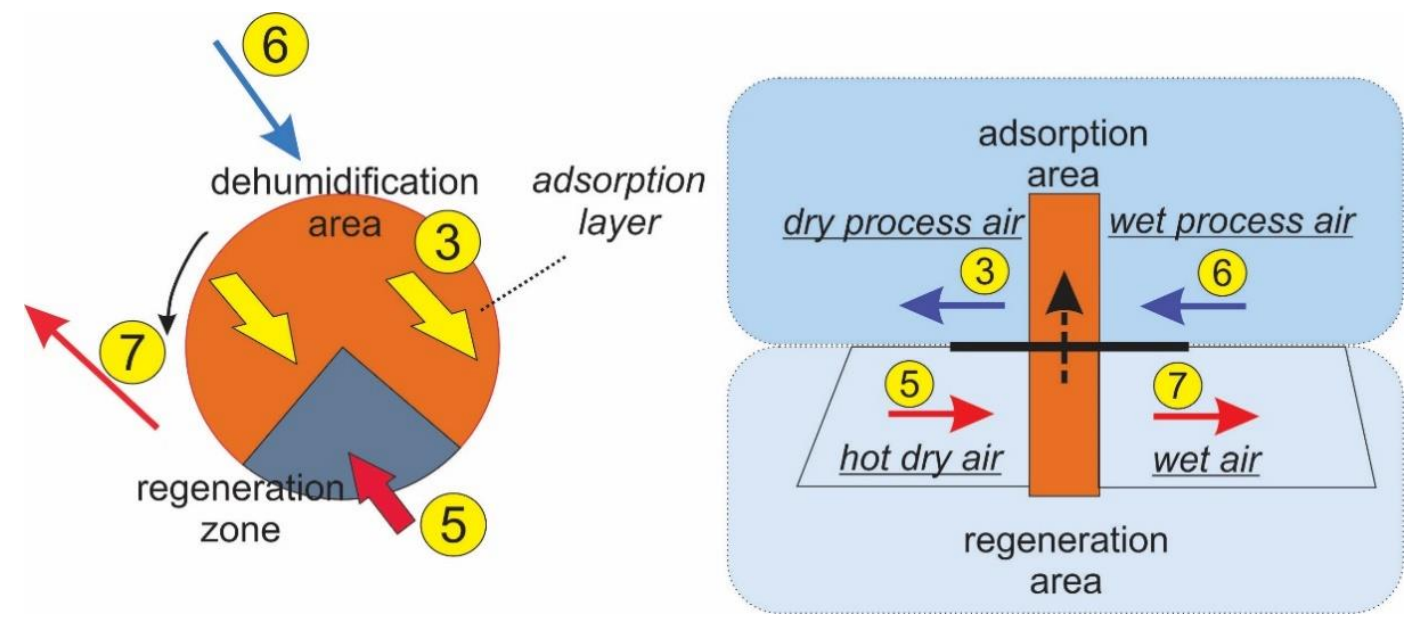

Fig. 2. Dehumidification system for air conditioning (Munters system) [18]

The Munters station works on the principle of temperature swing adsorption. It contains a sieve in the form of a wheel. There are channels whose walls are coated with an adsorption layer. The humid air goes through the adsorption sieve layer (Fig. 2). The percentage of dehumidification depends on the adsorption area, air moisture content and air flow. The sieve wheel is separated into two zones: one zone is used for air moisture adsorption and the other one is for recovering area for the adsorption layer. A great part of the wheel is the adsorption zone (Fig. 2). In that zone, the moisturized layer is renewed with hot dry air. At high temperatures, a low quantity of dry air can remove water and renew the adsorption layer. The adsorption sieve rotates all the time and forms two zones: the zone of dehumidification and the zone of adsorption layer recovery [18]. Additionally, the hot and the cold air that go through the adsorption layer of the Munters` system can exchange heat 
with the sieve material. During water adsorption, air exchanges heat with the hot adsorption layer as a result of temperature swing adsorption. The hot stream 5 is used for layer recovery. The exit stream (stream 7) has a lower temperature and higher moisture content. The temperature decrease is caused by the exchanged heat between the hot stream 5 and the adsorption layer, as well as other thermodynamic processes. The parameter values for process streams are given in Table 1.

Processes of air conditioning and yeast drying require different utilities. The analyzed system is supplied with a low pressure steam (LP steam), cold water and liquid ammonia. The main characteristics of the process are provided as follows.

- LP steam - saturated steam that supplies the entire production system with heat.

- Ammonia - a refrigerant used in the cooling system. Its minimum temperature is $-18^{\circ} \mathrm{C}$.
The cooling process is controlled with the evaporation of compressed ammonia liquid. Another purpose of this refrigerant is cooling in storage houses, storage tanks and temperature regulation of other cooling fluids.

- Cold water - industrial water used for cooling in processes that need temperatures higher than cold water supply temperature $\left(10^{\circ} \mathrm{C}\right)$.

\section{MATHEMATICAL MODEL OF PROCESSES}

Production or sub-systems can be described with mathematical relations between process parameters. In short, mass and heat balances of production processes are used for such purpose. In this case study, mass and heat balances were used for the analysis and simulation of a drying process. A drying sub-system DS was determined with equations 1 and 2.

$$
\begin{gathered}
\sum_{j \in I N(i, j)} m_{j}-\sum_{j \in O U T(i, j)} m_{j}=0 \quad, \forall i \in D S \\
\sum_{j \in I N(i, j)} m_{j}\left(h_{j}+\frac{c_{j}^{2}}{2}+g \cdot \xi_{j}\right)-\sum_{j \in O U T(i, j)} m_{j}\left(h_{j}+\frac{c_{j}^{2}}{2}+g \cdot \xi_{j}\right)-W_{j}+Q_{j}=0 \\
\forall j \in D S \quad \text { and } W_{j}=0, \mathrm{c}_{j}^{2}=0, \quad \xi_{j}=0
\end{gathered}
$$

Equation 1 represents the mass balance of all process streams $(j)$ that exist in the sub-system DS. The index $j$ is the process stream entering or exiting the subsystem. The process of drying Baker's yeast has no mass accumulation in any part of the plant, yet a small quantity exits the subsystem as dust. That mass is taken to be zero in these calculations. Heat balance is given by equation 2 , which expresses energy balance with included heat energy $\left(m_{j} \cdot h_{j}\right)$, kinetic energy $\left(m_{j} \frac{c_{j}^{2}}{2}\right)$, potential energy $\left(m_{j} \cdot g \cdot \xi_{j}\right)$, work $(W)$, and other possible chemical \& thermodynamic processes in real systems $(Q)$. The study case has only thermal energy balance (enthalpy of streams $h$ ) in this analyzed case. There are some assumptions for energy balance (eq. 2), such as kinetic and potential energy are zero. The interest here is only for heat content in fluids, but not their exergy values. Because of that, speed c and height $\xi$ are zero as well. Similarly, work $(W)$ is taken as non-existing or zero. Furthermore, the analyzed part of the production pro- cesses does not have any chemical reaction or heat storage (heat accumulation). According to all these assumptions, equation 2 can be simplified (eq. 3):

$$
\sum_{j \in I N(i, j)} m_{j} h_{j}-\sum_{j \in O U T(i, j)} m_{j} h_{j}=0 \quad \forall j \in D S
$$

Equations 1 and 3 are the basis for the simulation model. All parameters of streams, related to mass and heat balances, are used for simulation in MS Excel. Balance equations for consecutive processes are connected between themselves with the use of stream parameters (such as mass flow, temperature, pressure, etc.). Such parameters were used for calculations in the Excel worksheet (Fig. 1).

The next step is the selection of streams with potential for heat process integration [20]. The selection of streams was made on the basic principles of Pinch Technology. These selected streams were used to suggest two different scenarios as solutions. Both scenarios were analyzed and designed with Aspen HX-NET software. Each solution can have one or more constructed heat exchanger networks. The whole analysis is described in the next chapter of this paper. 


\section{PINCH ANALYSIS}

The Pinch analysis consists of the following consecutive steps [21]:

1. Data extraction from streams and utilities.

2. Targeting (design of composite curves, $\Delta T_{\min }$, optimal need of utilities, pinch point and hot and cold pinch temperatures).

3. Process modifications.

4. Network design (design of possible heat exchanger networks with maximum energy recovery).

5. Design evolution (rearrangement of Heat exchanger networks based on heat load loops and paths).

6. Process simulation.
The first step of the analysis began with data extraction. Values of the most important parameters like mass flow, heat capacity, supply temperature, target temperature and heat transfer coefficient of fluids were collected (Table 1) [22]. The expressions "hot stream" and "cold stream" are related to supply and target temperature values [23]. One of the most important parameters in heat transfer is heat transfer coefficient $(\alpha)$. The local heat transfer coefficient is connected with Nusselt criteria and can be calculated with equation 4 [14]. The Nusselt criteria depends on the Reynolds and Prandtl dimensionless number. That number also depends on the type of stream (cold or hot). The first line (equation 4) relates to cold streams (refrigerant and process streams: 4, 6, 17, 18, 19), the second line relates to hot streams (process streams 7 and 14) and the third line is only for steam.

$$
\alpha_{j}=f\left(N u_{j}\right)=\frac{\alpha \cdot L}{\lambda}=\left\{\begin{array}{l}
0.023 \cdot \operatorname{Re}^{0.8} \operatorname{Pr}^{0.33}, j \in \text { refrigerant }, 4,6,17,18,19 \\
0.026 \cdot \operatorname{Re}^{0.6} \operatorname{Pr}^{0.3}, j \in 7,14 \\
0.021 \cdot \operatorname{Re}^{0.8} \operatorname{Pr}^{0.43} \cdot 0.5 \cdot\left[1+\left(\frac{\rho_{f}}{\rho_{g}}\right)^{0.5}\right], j \in \text { steam }
\end{array}\right\}
$$

All air streams $(17,18,19)$ that are heated upon entrance of the dryer are potential cold streams for heat integration. Stream 4 requires a high heat load to get the target temperature. That cold stream can be heated by a portion of the hot process stream. If there is not enough heat and driving force, the additional heating can be conducted with a heater. The exit process streams 7 and 14 contain surplus heat that can be reused for heating of some cold streams. Stream 6 is dewatered and can be potentially used as a cold one. All streams were combined into two possible scenarios as solutions.

Steps $2-6$ were made with ASPEN HXNET software and conducted for two different cases (scenarios). The first suggested case contains the following streams: hot stream 7 , and cold streams 4, 17, 18 and 19 (Table 1). In the second case, cold stream 6 and hot stream 14, without stream 18 (Table 1) were added. In that case, there is a possibility for heating of stream 6 to a slightly higher temperature, which can raise the temperature in the stream 3 (Fig. 1). The temperature of stream 3 can be regulated with automatic control and connected with heating of stream 6 . Therefore, the tempera- ture of exiting dry air from Munters system can be set to $44.5^{\circ} \mathrm{C}$. A possible temperature change in stream 6 is $12.6^{\circ} \mathrm{C}$, which was taken as an assumption for further calculations. The temperature of stream 3 would become the same as target temperature of stream 18. Therefore, stream 18 does not need heating and was not included in this scenario. All selected process streams for both scenarios are given in Table 1.

"Targeting" as a next step calculates the pinch point and the optimal $\Delta T_{\min }$ to achieve the maximal energy recovery. The optimal value of $\Delta T_{\min }$ in heat exchanger networks was determined from operating cost, capital cost and total cost. Operating cost is determined from the cost of utilities and was calculated for hot and cold utilities needed for heating and cooling (Eq. 5). The price of hot utility $\left(\mathrm{C}_{\mathrm{HU}}\right)$ was estimated from equation 6 , which uses the lowest $\left(h_{a}\right)$ and the highest $\left(h_{s}\right)$ energy content of fuel oil, as well as efficiency of boiler $(\eta)$ in generation of steam. Additionally, the steam price depends on its physical properties and the price of fuel oil $\left(\mathrm{C}_{\mathrm{F}}\right)$. Moreover, the price of cold utility $\left(\mathrm{C}_{\mathrm{CU}}\right)$ was taken as its real value from the industrial water supply company. All data from 
selected streams were used in design of heat exchanger networks.

$$
\begin{gathered}
O C=C_{H U} \cdot Q_{H U, \text { min }}+C_{C U} \cdot Q_{C U, \text { min }} \\
C_{H U}=C_{F} \cdot \frac{l \cdot\left(h_{s}-h_{a}\right)}{\eta \cdot H d} \cdot 10^{6}
\end{gathered}
$$

All costs used for Pinch analysis were made with ASPEN HX-NET software. The created solutions are given in the following chapter.

\section{RESULTS AND DISCUSSION}

The drying system was analyzed for a possible heat integration. There were selected cold and hot streams that satisfy Pinch Technology requirements. These combinations of selected streams created two basic scenarios and one modified scenario. All of these scenarios are explained in the following text.

Scenario 1 - is made from selected cold streams 4, 17, 18, 19 and hot stream 7 (Table 2). Stream 7 is the main heat source, as it contains waste heat from adsorption layer recovery with temperature of $61.6^{\circ} \mathrm{C}$, allowing for heat to recirculate between the Munters system and inlet dry air streams.
All selected streams and their parameters for each scenario are provided in Table 2. Parameter values of streams were entered in HX-NET software, which helps find pairs of hot and cold streams and can match the possibility of heat transfer. Units used for heat transfer between these pairs of streams are heat exchangers (HE). All scheduled heat exchangers create a network. The network created with heat exchanges and pairs of hot and cold streams is known as heat exchanger networks (HENs). The value of $\Delta \mathrm{T}_{\min }$ was $8{ }^{\circ} \mathrm{C}$ for the Scenario 1 , and $6{ }^{\circ} \mathrm{C}$ for Scenario 2. These minimum temperature differences are the result of determined crossing point between curves of capital cost, operating cost and total cost. Capital cost was calculated from the estimated cost of heat exchangers that have to be installed for each scenario (eq. 8 and 9). The cost indices in equation 8 have the following values: $a=10000, b=800, c=0.8$. The rate of return and plant life were taken to be 0.1 and 10 years, respectively. Operating costs were determined with equations 5 and 6 , while equation 7 is used for the calculation of total cost (TC) as the sum of capital cost (CC) and operating cost (OC). The pinch point value for scenario 1 is calculated as $44^{\circ} \mathrm{C}$ (hot pinch point is $48{ }^{\circ} \mathrm{C}$ and cold pinch point is $40^{\circ} \mathrm{C}$ ). The second scenario has a Pinch point at temperature of $47.5^{\circ} \mathrm{C}$ (hot pinch point is $50.5^{\circ} \mathrm{C}$ and cold pinch point is $44.5^{\circ} \mathrm{C}$ ).

$$
T C=C C+O C
$$

\begin{tabular}{|c|c|c|c|c|c|c|c|}
\hline \multirow{2}{*}{ Stream } & \multirow{2}{*}{ Scenario } & \multicolumn{2}{|c|}{ Temperature $\left[{ }^{\circ} \mathrm{C}\right]$} & \multirow{2}{*}{$\begin{array}{c}m \mathrm{c}_{\mathrm{p}} \\
{\left[\mathrm{kW} /{ }^{\circ} \mathrm{C}\right]}\end{array}$} & \multirow{2}{*}{$\begin{array}{c}\Delta Q \\
{[\mathrm{~kW}]}\end{array}$} & \multirow{2}{*}{$\alpha\left[W / \mathrm{m}^{2} \mathrm{~K}\right]$} & \multirow{2}{*}{ Stream type } \\
\hline & & $T_{\text {supply }}$ & $T_{\text {target }}$ & & & & \\
\hline \multirow{2}{*}{4} & 1 & 40.0 & 86.5 & 1.94 & 90.2 & 2.24 & Cold \\
\hline & 2 & 44.5 & 86.5 & 1.94 & 81.5 & 2.24 & Cold \\
\hline \multirow{2}{*}{17} & 1 & 40.0 & 87.0 & 3.51 & 165.0 & 3.20 & Cold \\
\hline & 2 & 44.5 & 87.0 & 3.51 & 149.2 & 3.20 & Cold \\
\hline \multirow{2}{*}{18} & 1 & 40.0 & 44.5 & 1.59 & 7.2 & 1.99 & Cold \\
\hline & 2 & 44.5 & 44.5 & 0.00 & 0.0 & 1.99 & Cold \\
\hline \multirow{2}{*}{19} & 1 & 40.0 & 49.3 & 0.87 & 8.1 & 1.38 & Cold \\
\hline & 2 & 44.5 & 49.3 & 0.87 & 4.2 & 1.38 & Cold \\
\hline 6 & 2 & 8.1 & 12.6 & 8.03 & 36.1 & 4.99 & Cold \\
\hline \multirow{2}{*}{7} & 1 & 61.6 & 30.0 & 2.05 & 64.8 & 2.31 & Hot \\
\hline & 2 & 68.1 & 30.0 & 2.05 & 78.1 & 2.31 & Hot \\
\hline 14 & 2 & 38.0 & 20.0 & 0.88 & 15.8 & 1.38 & Hot \\
\hline HU & Steam & 250.0 & 249.0 & - & - & 3.52 & Hot \\
\hline $\mathrm{CU}$ & Cold water & 2.0 & 10.0 & - & - & 1.50 & Cold \\
\hline
\end{tabular}

Table 2

Characteristics of selected streams for Process Integration of suggested scenarios

A solution for this scenario is proposed in Figure 3. In this HEN, only streams 4 and 17 are heated with steam. These heaters are already in- stalled $\mathrm{HU}_{3}$ and $\mathrm{HU}_{4}$. Because of that, these heaters were not calculated as new ones. Process stream 7 (stream with surplus heat), can be used to 
heat any cold stream. Stream 17 is partially heated by stream 7 (via $H_{1}$ ). The rest of the heat is supplied by an old heater $\left(\mathrm{HU}_{3}\right)$ to achieve the target temperature of $87^{\circ} \mathrm{C}$. Stream 7 has a target temperature of $30^{\circ} \mathrm{C}$. Achieving this target temperature requires additional cooling with cold water, yet this stream is a waste stream so there is no real need for extra cooling. Avoiding the cooling for stream 7 will decrease operating costs. As such, the new target temperature was set at $50{ }^{\circ} \mathrm{C}$. This temperature in stream 7 is the minimum possible solu- tion for this scenario. In this case, streams 18 and 19 are completely heated with stream 7 . These two streams require two new heat exchangers $\mathrm{HE}_{2}$ and $\mathrm{HE}_{3}$ (Fig. 3). As a result of the heat process integration, this scenario requires the installation of three new heat exchangers: $\mathrm{HE}_{1}, \mathrm{HE}_{2}$ and $\mathrm{HE}_{3}$ (Fig. 4). The duty of these heat exchangers is $7.6 \mathrm{~kW}$ $\left(\mathrm{HE}_{1}\right), 7.2 \mathrm{~kW}\left(\mathrm{HE}_{2}\right)$ and $8.1 \mathrm{~kW}\left(\mathrm{HE}_{3}\right)$, respectively. The total combined heat recovery is 22.9 $\mathrm{kW}$ as a sum of the heat transferred through them.

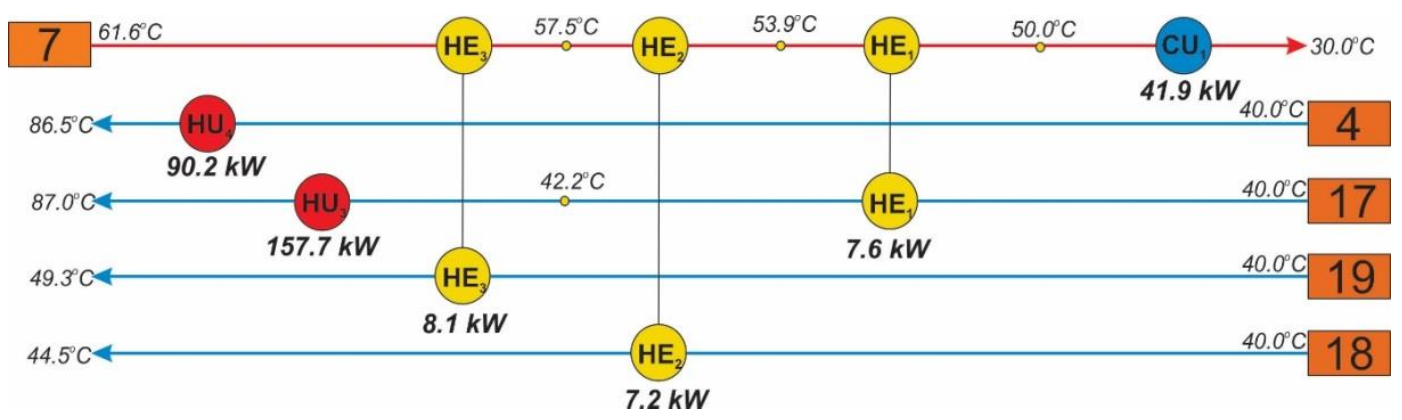

Fig. 3. Heat Exchangers Network (HEN) as solution for Scenario 1

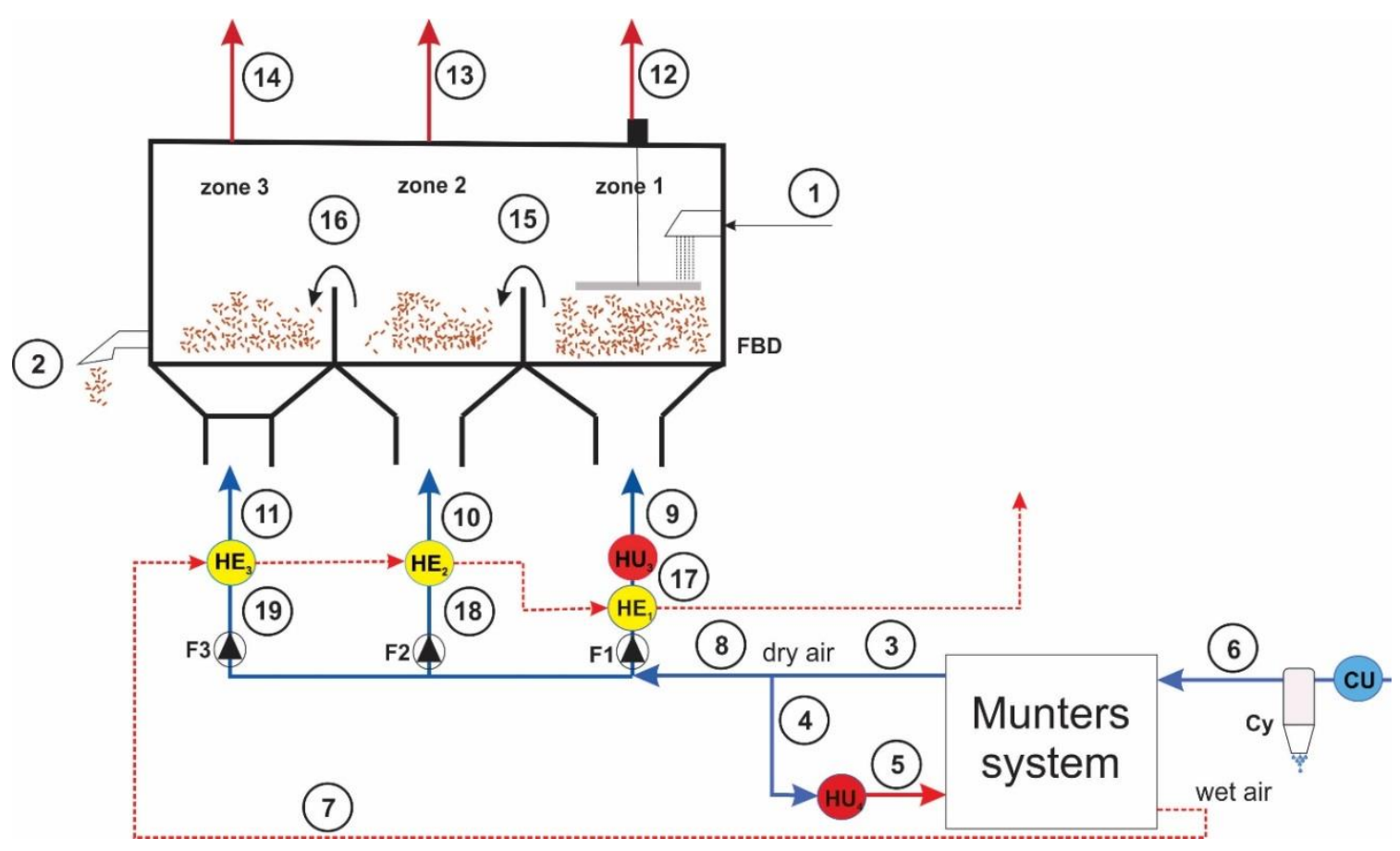

Fig. 4. Process scheme with all heat exchangers included in solution for Scenario 1

Scenario 2 - involves hot streams 7 and 14 and cold streams $4,6,17,18,19$. Stream 7 , as it was explained in scenario 1 , can be used as the main source of heat for other selected streams (preheating). Stream 14 is the exit stream from zone 3 in the fluidized bed dryer with temperature of 38
${ }^{\circ} \mathrm{C}$. Both streams 7 and 14 exit the system. While their target temperatures are changeable, they were set on their optimal values (Table 2). The strategy for this scenario is the possibility for additional heating of stream 6 on the inlet of Munters system. The target temperature of stream 6 would control 
the exit temperature of stream 3. That temperature was the same with the lowest supply temperature in the drying system (drying zones). Its lowest supply target temperature is the temperature of stream $18\left(44.5^{\circ} \mathrm{C}\right)$. This change will cause the same supply temperatures for cold streams 4,17 , 18 and $19\left(44.5^{\circ} \mathrm{C}\right)$. In the current drying process, stream 18 goes through the heater that controls its target temperature. As such, stream 18 has no need for any additional heating. This change in the drying system influences the change of temperatures involved in the Munters system. If there is a mass and heat balance, there will be an increase in the exit temperature of stream 7 (Table 2).
Two different HEN designs were suggested as solutions for scenario 2 (Fig. 5). This solution reuses the heat from hot streams 7 and 14 for the complete heating of cold streams 6 and 19, while stream 7 partially satisfies the heat demand for stream 17. The rest of the heat is received from heater $\mathrm{HU}_{3}$ (Fig. 5). Stream 4 can be completely heated only with steam through $\mathrm{HU}_{4}$. Heaters $\mathrm{HU}_{3}$ and $\mathrm{HU}_{4}$ already exist in the system (Fig. 1). The design of heat exchanger network (Fig. 5) requires four new heat exchangers: $\mathrm{HE}_{1}, \mathrm{HE}_{2}, \mathrm{HE}_{3}$ and $\mathrm{HE}_{4}$. The total duty of these heat exchangers is $81.8 \mathrm{~kW}$, which is the heat recovered for this scenario. The value of recovered heat was used for further economic calculations.

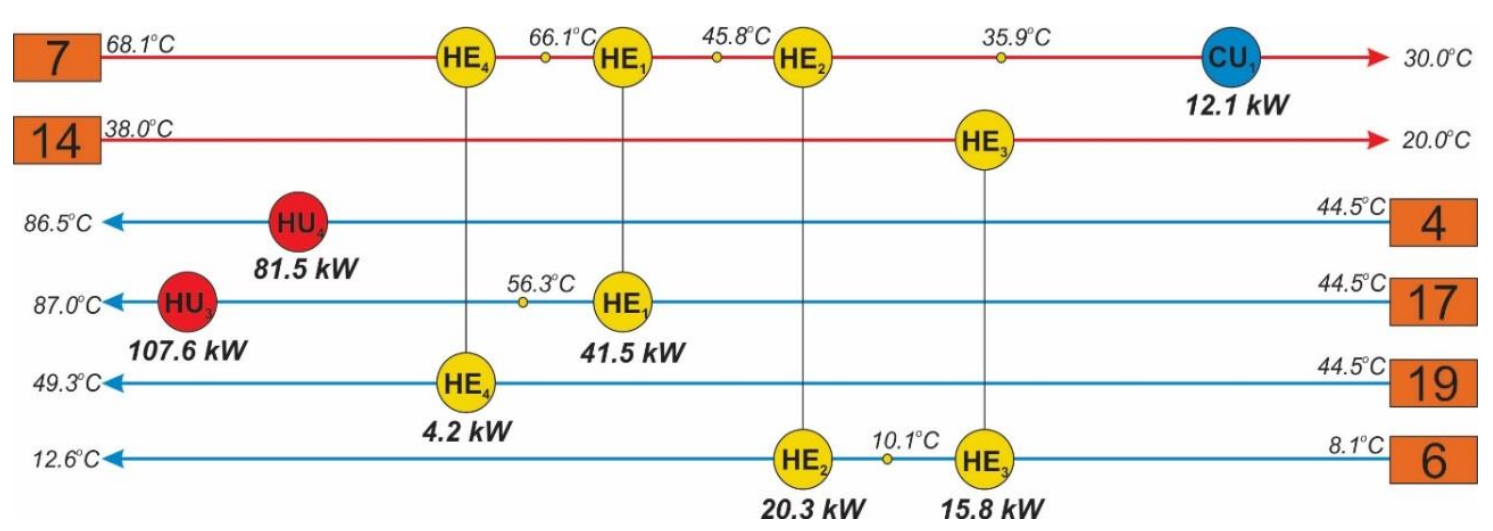

Fig. 5. Heat Exchangers` Network (HEN - design 1) as solution for Scenario 2

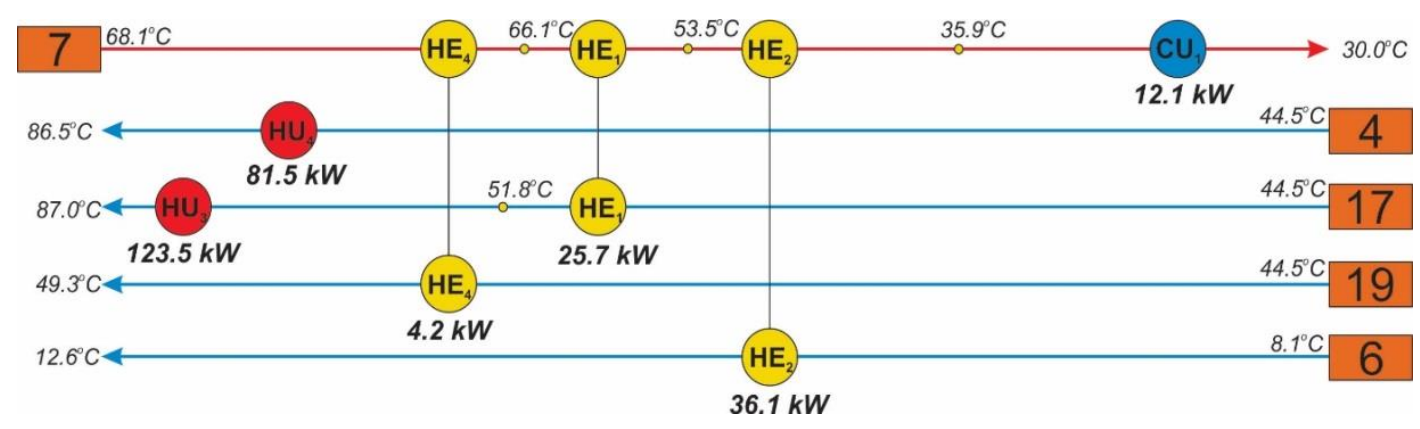

Fig. 6. Modified solution (HEN - design 2) for Scenario 2

If the solution for scenario 2 is observed, some modifications are possible (Fig. 6). Stream 7 has enough surplus heat to completely heat stream 6 which will decrease the number of heat exchangers. In this situation, stream 14 is never used. According to Pinch Technology, stream 14 should be cooled with a cooler to get its target temperature, yet it is a waste stream, which is the main reason why it is not used for further heat integration. Stream 7 is also waste stream and therefore does not need additional cooling by $\mathrm{CU}_{1}$. If these state- ments are used in the solution, a new modified heat exchanger network can be created (Fig. 7). The new final solution requires 3 new heat exchangers, although heaters scheduled in this design already exist in the real system. The total heat recovered $(66 \mathrm{~kW})$ with this modification is the sum of the heat duties of 3 new heat exchangers. This value is lower than the previously suggested solution for scenario 2. Both solutions for scenario 2 are provided in Figure 8. The economic analysis will determine the best solution for both scenarios. 


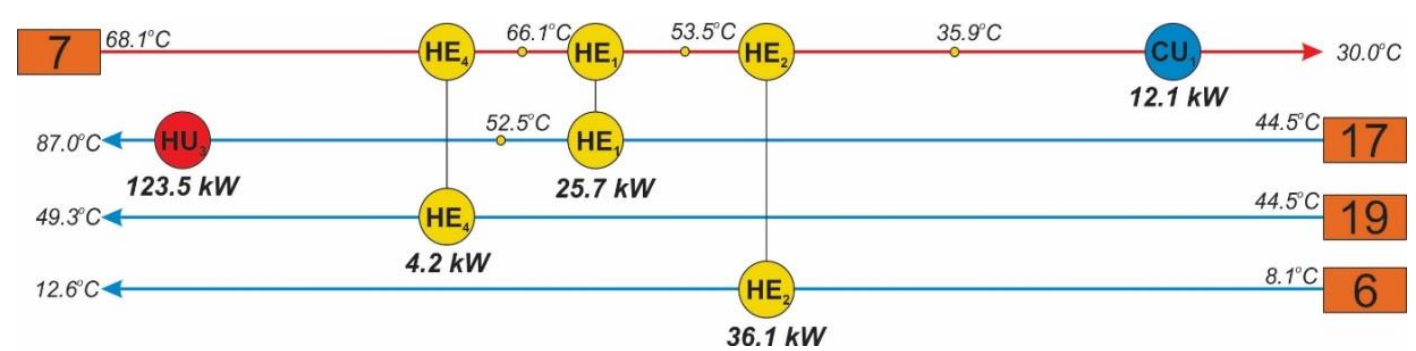

Fig. 7. Final design of heat exchangers network (HEN) for modified Scenario 2

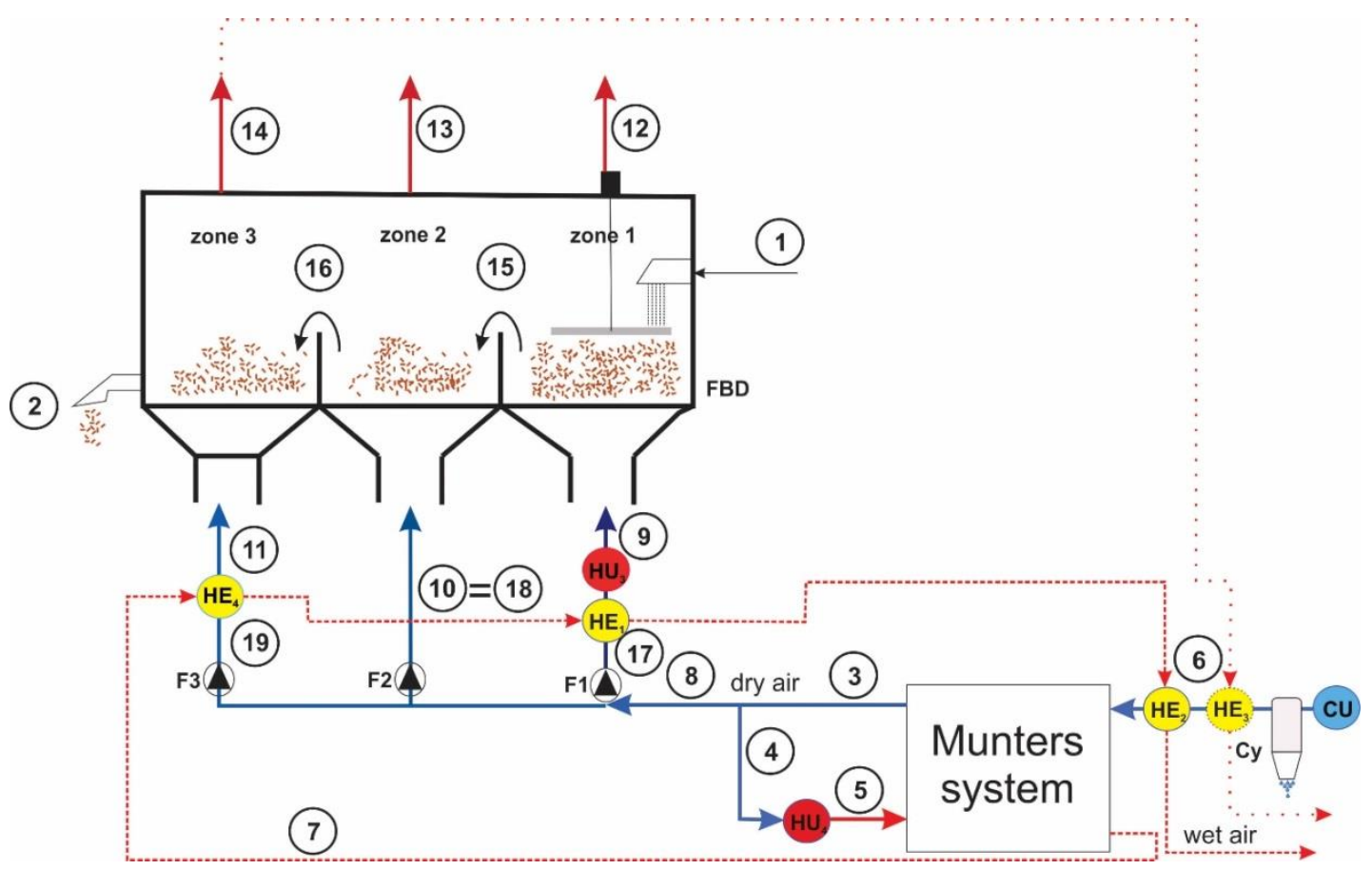

Fig. 8. Process scheme of modified solution for Scenario 2, including new and old heat exchangers

The next step is an economic analysis of all suggested solutions. The economic analysis was made with calculations of capital cost, profit and economic parameters. Capital cost and annualized factor were needed for cost estimation of the new heat exchangers (eqs. 8, 9). For this purpose, the following values of economic parameters were taken as pre-requirements: rate of return $(\mathrm{ROR}=$ $10 \%)$, plant life (PL $=10$ years), operating hours (8500 hours per year) and number of shells $(n=1)$. The value of the heat transfer area $(A)$ was calculated by using the BATH equation (eq. 10).

$$
\begin{gathered}
C C=A F \cdot\left[a+b \cdot\left[\frac{A}{n}\right]^{c \cdot n}\right] \\
A F=\frac{\frac{R O R}{100} \cdot\left[1+\frac{R O R}{100}\right]^{P L}}{\left[1+\frac{R O R}{100}\right]^{P L}-1}
\end{gathered}
$$

$$
\begin{aligned}
& A_{\min }=\sum_{k} \frac{1}{\Delta T_{k}} \cdot \sum_{j} \frac{\Delta Q_{j}}{h_{j}} \\
& j \in \text { streams } \\
& k \in \text { enthalpy intervals }
\end{aligned}
$$

The estimated operating costs for the given scenarios were calculated from the price of the heating utility (eq. 5). While additional cooling is minimized to zero (suggested solutions), reducing the demand for heating utilities makes the difference in operating cost before and after investing in scenarios. That difference was considered the profit (eq. 11).

$$
\begin{aligned}
& \text { profit }_{\text {heat recovery }}=P_{H U} \cdot\left(Q_{H U_{0}}-Q_{H U_{m, n}}\right)+P_{C U} \cdot\left(Q_{C U_{0}}-Q_{C U_{m, n}}\right) \\
& \text { where } \quad m \in \Delta T_{\min }, \quad n \in\{\text { scenario } 1 \text {, scenario } 2\}
\end{aligned}
$$

The cash flow analysis of the capital cost investment and profit for a project life of 10 years provides a better solution. The calculated values 
for the capital cost and the profit from heat recovery are shown in Table 3 . The estimated cost for heating utility was already determined as 23.41 $€ / G J$, with an 0.1 (10\% annual) interest rate.

The cash flow analysis determines the following economic parameters: pay back period $(\mathrm{PBP})$, rate of return on investment (ROROI) and net present value (NPV). Pay back period (eq. 12) is the period of time (in years) required for the project investment to be returned from revenues or profit. The values of these economic parameters are given in Table 3. The rate of return on investment (ROROI) shows the intensity of returning the investment (given in Table 3 as the ratio and the percentage of returned money from incomings). Higher ROROI values suggest a higher intensity of return as well as a shorter period of money return. ROROI mathematically means the ratio between the average incomes and the capital investment cost (eq. 13). As such, any income used in ROROI calculations is pure profit determined after tax.

Table 3

Heat recovery and economic parameters for each scenario

\begin{tabular}{|c|c|c|c|}
\hline Scenario & Scenario 1 & $\begin{array}{l}\text { Scenario } 2 \\
\text { (design } 1)\end{array}$ & $\begin{array}{l}\text { Scenario 2 } \\
\text { (design 2) }\end{array}$ \\
\hline Number of new heat exchangers & 3.0 & 4.0 & 3.0 \\
\hline Duty of new installed heat exchangers [kW] & 22.9 & 81.8 & 66.0 \\
\hline Capital cost for additional heat exchangers $[€]$ & $51,400.0$ & $191,627.9$ & $67,995.6$ \\
\hline Heat recovery $[\mathrm{kW}]$ & 22.9 & 81.8 & 66.0 \\
\hline Heat recovery [GJ/year] & 700.7 & $2,503.0$ & $2,019.6$ \\
\hline Annual profit from heat recovery [€/year] & $16,404.3$ & $58,597.1$ & $47,278.8$ \\
\hline $\begin{array}{l}\text { Economic parameter } \\
\text { Pay back period (PBP) [years] }\end{array}$ & 4.64 & 5.93 & 2.05 \\
\hline $\begin{array}{l}\text { Economic parameter } \\
\text { Rate of return on investment (ROROI) }\end{array}$ & 0.21 & 0.17 & 0.49 \\
\hline $\begin{array}{l}\text { Economic parameter } \\
\text { Rate of return on investment (ROROI) [\%] }\end{array}$ & $21 \%$ & $17 \%$ & $49 \%$ \\
\hline $\begin{array}{l}\text { Economic parameter } \\
\text { Net present value (NPV) }[€]\end{array}$ & $55,565.6$ & 168426.0 & $222,512.4$ \\
\hline
\end{tabular}

$$
\begin{gathered}
P B P=\frac{P L \cdot C_{\text {invest }}}{\sum_{i=1}^{P L} C F_{(\text {affertax }) i}}=\frac{1}{R O R O I} \\
R O R O I=\frac{\text { average annual net income }}{C C}=\frac{\sum_{i=1}^{P L} C F_{(\text {affertax }) i}}{P L \cdot C_{\text {invest }}}
\end{gathered}
$$

The results of the economic calculations for these scenarios are provided in Table 3 . Based on these results, it appears that the modified solution for scenario 2 is the most profitable, with a fast payback period of 2.05 years. On the other hand, other solutions have the longer payback periods of 4.64 and 5.93 years. Similarly, the rate of return on investment is much bigger in the modified solution for scenario $2($ ROROI $=0.49)$ than scenario 1 $(\mathrm{ROROI}=0.21)$. Therefore, the best solution is the modified HEN for scenario 2; an intermediate solution is that for scenario 1. Finally, the worst is the suggested non-modified solution for scenario 2 . Moreover, the heat recovery changed the heat de- mand per product. The heat demand in the primary case (without heat integration) for the production of active dry baker`s yeast is $2.07 \mathrm{kWh} / \mathrm{kg}$ dry product. Heat recovery for the first scenario reduced the heat demand to $1.90 \mathrm{kWh} / \mathrm{kg}$ dry product. The second scenario reduced the heat demand for the HEN design 1 to $1.44 \mathrm{kWh} / \mathrm{kg}$ dry product. The demand for modified design 2 became 1.57 $\mathrm{kWh} / \mathrm{kg}$ dry product.

The solution of the heat recovery problem was analyzed with Pinch Technology, providing a few possible solutions with different amounts of heat recovery. Scenario 2 with design 1 has maximal recovery, although that data is not sufficient 
for making investment decisions. The judgment of process managers on their choice between a few different solutions or projects must be based on the profitability of changes in the production system. For one, they would need to invest in new equipment. That cost must be covered with fresh incomes from the realization of the selected project. The final decision for any possible investment in any of these scenarios should be based on other economic factors. The modified solution for scenario 2 was determined as the best option, because it would produce the highest profit and a faster return of invested money.

Error analysis - Designs of heat exchanger networks were made with HX-NET software. The above-mentioned solutions were simulated, showing the variations between the simulated and operating values of the parameters (Table 4).

Table 4

Operating values of parameters and their values from the simulation of the drying system

\begin{tabular}{ccccc}
\hline \hline Stream & \multicolumn{2}{c}{ Pressure $[\mathrm{kPa}]$} & \multicolumn{2}{c}{ Flow $[\mathrm{kg} / \mathrm{h}]$} \\
\hline & $\begin{array}{c}\text { Operating } \\
\text { values }\end{array}$ & $\begin{array}{c}\text { Simulation } \\
\text { values }\end{array}$ & $\begin{array}{c}\text { Operating } \\
\text { values }\end{array}$ & $\begin{array}{c}\text { Simulation } \\
\text { values }\end{array}$ \\
\hline 3 & 95.6 & 96.2 & 28339.2 & 28209.1 \\
4 & 95.6 & 96.2 & 6915.6 & 6867.4 \\
5 & 94.1 & 90.0 & 6915.6 & 6867.4 \\
6 & no data & 96.3 & 28399.3 & 28399.4 \\
7 & 93.7 & 95.0 & 7056.0 & 7056.3 \\
10 & 90.3 & 96.1 & 12549.6 & 12551.2 \\
11 & 95.2 & 96.1 & 5691.6 & 5690.0 \\
12 & - & 96.1 & 3099.6 & 3100.5 \\
17 & 95.6 & 96.2 & 12549.6 & 12551.2 \\
18 & 95.6 & 96.2 & 5691.6 & 5690.0 \\
19 & 95.6 & 96.2 & 3099.6 & 3100.5 \\
\hline \hline
\end{tabular}

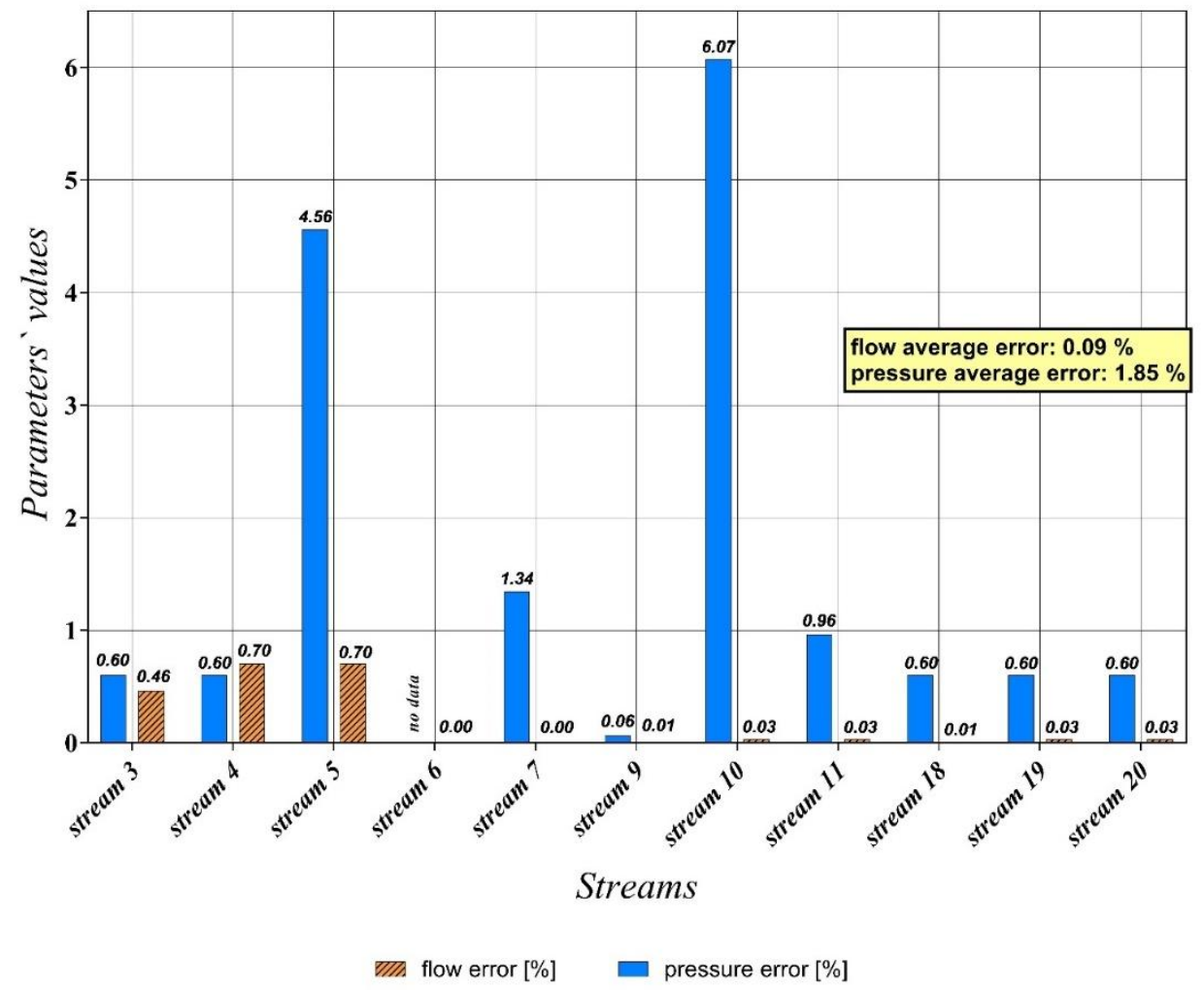

Fig. 9. Error analysis from simulated drying subsystem (flow error and pressure error) 
Certain parameters such as pressure and mass flow were compared with the real values. The simulation was based on values of process temperatures, so there is no simulation error for temperature. The result of error analysis is shown in Figure 9, where the calculated errors of parameters from simulation are provided for data validation. The average error for pressure is $1.85 \%$; the flow error is $0.09 \%$.

\section{CONCLUSION}

This work analyzes a system with high heat demand using heat process integration. With this technique, the possibility for heat recovery in a baker's yeast drying sub-system was determined and two scenarios were suggested. Each scenario was solved through the design of a heat exchanger network. The major impact of this analysis and the designed solutions was the decrease in operating cost, which will affect the price of the active dry yeast at the same time.

Process integration, as well as Pinch Technology, provide many opportunities for heat recovery in food-processing industries. Given that the results improve the heat efficiency of designed heat recovery networks, the networks can recover different amounts of heat. However, the values for cost and profit are unique for each one. This research suggests three designs which range in economic influence and possible investments. The chosen scenario saves $66 \mathrm{~kW}$ and has the best economic results. The simulation of results improves the possibilities for the use of any of suggested solutions. However, some phenomena like thermodynamic effects in temperature swing adsorption were not analyzed. In addition, this case study is taken as an ideal system without loss of heat. The changes of heat content during the process can be described with exergy, which includes mechanical work, internal energy and energy loses. The consequences of these effects will be analyzed in future research.

\section{REFFERENCES}

[1] B. Linnhoff, Pinch analysis: a state-of-art overview, Comput. Chem. Eng., 71, 503-22 (1993).

[2] M. Türker, A. Kanarya, U. Yüzgeç, H. Kapucu, Z. Şenalp, Drying of baker's yeast in batch fluidized bed, Chem. Eng. Process Intensif, 45, 1019-1028 (2006). DOI: 10.1016/j.cep.2006.01.016.

[3] H. Akbari, K. Karimi, M. Lundin, M. J. Taherzadeh. Optimization of baker's yeast drying in industrial continuous fluidized bed dryer, Food Bioprod Process, 90, 52-7 (2012). DOI: 10.1016/j.fbp.2010.12.005.
[4] P. Sebastian, J. P. Nadeau, J. R. Puiggali. Designing dryers using heat and mass exchange networks: an application to conveyor belt dryers, Chem. Eng. Res. Des. 74, 934-43 (1996). DOI: 10.1205/026387696523102.

[5] M. R. W. Walmsley, T. G. Walmsley, M. J. Atkins, P. J. J. Kamp, J. R. Neale, A. Chand, Carbon emissions pinch analysis for emissions reductions in the New Zealand transport sector through to 2050, Energy, 92, 569-76 (2015). DOI: 10.1016/j.energy.2015.04.069.

[6] T. G. Walmsley, M. R. W. Walmsley, A. H. Tarighaleslami, M. J. Atkins, J. R. Neale, Integration options for solar thermal with low temperature industrial heat recovery loops, Energy, 90, 113-21 (2015). DOI: 10.1016/j.energy.2015.05.080.

[7] T. G. Walmsley, M. R. W. Walmsley, M. J. Atkins, J. R. Neale, A. H. Tarighaleslami, Thermo-economic optimisation of industrial milk spray dryer exhaust to inlet air heat recovery, Energy, 90, 95-104 (2015). DOI:10.1016/j.energy.2015.03.102.

[8] T. G. Walmsley, M. J. Atkins, M. R. W. Walmsley, J. R. Neale, M. Philipp, G. Schumm et al., Total site utility systems optimisation for milk powder production, Chem. Eng. Trans., 52, 235-40 (2016). DOI: $10.3303 /$ CET1652040.

[9] S. Heyne, S. Harvey, Production of synthetic natural gas from biomass-process integrated drying. ECOS 2009 22nd Int. Conf. Effic. Cost, Optim. Simul. Environ. Impact Energy Syst., 2009.

[10] O. P. Arsenyeva, L. Čuček, L. L. Tovazhnyanskyy, P. O. Kapustenko, Y. A. Savchenko, S. K. Kusakov, et al., Utilisation of waste heat from exhaust gases of drying process, Front. Chem. Sci. Eng., 10, 131-8 (2016). DOI: $10.1007 / \mathrm{s} 11705-016-1560-8$.

[11] L. Sivill, P. Ahtila, Energy efficiency improvement of dryer section heat recovery systems in paper machines A case study, Appl. Therm. Eng., 29, 3663-8 (2009). DOI: 10.1016/j.applthermaleng.2009.06.022.

[12] L. Sivill, P. Ahtila, M. Taimisto, Thermodynamic simulation of dryer section heat recovery in paper machines, Appl. Therm. Eng., 25, 1273-92 (2005). DOI: 10.1016/j.applthermaleng.2004.09.002.

[13] A. Anastasovski, P. Rašković, Z. Guzović, Design and analysis of heat recovery system in bioprocess plant, Energy Convers Manag., 104, 32-43 (2015). DOI:10.1016/j.enconman.2015.06.081.

[14] P. Rašković, A. Anastasovski, L. Markovska, V. Meško. Process integration in bioprocess indystry: waste heat recovery in yeast and ethyl alcohol plant, Energy, 35, 704-17, (2010). DOI:10.1016/j.energy.2009.11.020.

[15] A. E. Kabeel, M. H. Hamed, Z. M. Omara, A. W. Kandeal. Solar air heaters: Design configurations, improvement methods and applications - A detailed review. Renew Sustain Energy Rev 2017;70:1189-206. DOI: 10.1016/J.RSER.2016.12.021.

[16] G. Cavazzini, P. Dal Toso, Techno-economic feasibility study of the integration of a commercial small-scale ORC in a real case study, Energy Convers Manag.; 99, 161-75 (2015). DOI: 10.1016/j.enconman.2015.04.043.

[17] I. Kemp Pinch Analysis and Process Integration (A user guide on process integration for the efficient use of energy). Oxford, Butterworth-Heinemann as imprint of Elsevier, 2007. 
[18] Munters. Munters 2017. https://www.munters.com/ en/munters/case-studies/diserod-water-pumping-station-/ (accessed May 31, 2017).

[19] Munters. Dehumidifying Diseröd Pumping Station prevents corrosion, 2017. https://www.munters.com/en/ (accessed June 8, 2017).

[20] J. J. Klemeš, 36 - Epilogue: The importance of problem formulation and data extraction in process integration, Handb. Process Integr., 2013, p. 1099-116. DOI: 10.1533/9780857097255.6.1099.

\section{ABREVIATIONS}

A - heat transfer area $\left[\mathrm{m}^{2}\right]$

$\mathrm{a}, \mathrm{b}, \mathrm{c}$ - factors for heat exchanger capital cost

$\mathrm{AF}$ - annualized factor

$\mathrm{C}-$ cost [currency]

$\mathrm{C} \mathrm{c}-$ fluid velocity $[\mathrm{m} / \mathrm{s}]$

$\mathrm{CC}$ - capital cost [currency, $€$ ]

$\mathrm{CF}$ - Cash Flow [currency]

$\mathrm{Cp}$ - heat capacity $[\mathrm{kJ} / \mathrm{kg} \mathrm{K}]$

$\mathrm{CU}$ - cooler, cold utility

$\mathrm{Cy}$ - cyclone

DM - Dry matter [\%]

DS - drying subsystem

F - fuel

f - liquid

FDB - Fluidized Bed Dryer

g - gravity $\left(9.81 \mathrm{~N} / \mathrm{m} \mathrm{s}^{2}\right)$

$\mathrm{h}$ - specific enthalpy $[\mathrm{J} / \mathrm{kg}]$

$\mathrm{h}_{\mathrm{a}}$-lowest fuel enthalpy $[\mathrm{J} / \mathrm{kg}]$

HE - Heat Exchanger

HEN - Heat Exchanger Network

$\mathrm{h}_{\mathrm{s}}$ - highest fuel enthalpy $[\mathrm{J} / \mathrm{kg}]$

HU - heater, hot utility

j-stream

$\mathrm{k}$ - enthalpy intervals

$\mathrm{L}, \mathrm{l}$ - length, pipe diameter [m]

$\mathrm{m}-$ mass flow $[\mathrm{kg} / \mathrm{s}]$

$\mathrm{n}$ - number of shells, number of years (economics)

NPV - Net Present Value [currency, $€$ ]

$\mathrm{Nu}$ - Nuselt number

OC - Operating Cost [€/ year]

$\mathrm{P}$ - price [currency, $€$ ]

PBP - Pay Back Period [years]

PI - Process Integration

PL - Project life

$\operatorname{Pr}-$ Prandtl dimensionless number

$\mathrm{Pr}-$ Prandtl number

$\mathrm{Q}$ - heat load, duty [kW]

$\mathrm{Re}$ - Reynold dimensionless number

RH - Relative Humidity [\%]

ROR - rate of return

ROROI - Rate of Return on Investment

$\mathrm{T}$ - temperature $\left[{ }^{\circ} \mathrm{C}\right]$

TC - Total Cost [currency]

$\mathrm{W}$ - work [kJ]

$\alpha$ - heat transfer coefficient $\left[\mathrm{W} / \mathrm{m}^{2} \mathrm{~K}\right]$

$\Delta \mathrm{T}_{\min }$ - minimal temperature difference $\left[{ }^{\circ} \mathrm{C}\right]$

$\eta$ - efficiency

$\lambda$ - thermal conductivity of fluid $[\mathrm{W} / \mathrm{mK}]$

$\xi$ - height $[\mathrm{m}]$
[21] T. Gundersen, 4 - Heat Integration: Targets and Heat Exchanger Network Design, Handb. Process Integr., 2013, p. 129-67. DOI:10.1533/9780857097255.2.129.

[22] I. C. Kemp, Batch and Time-dependent Processes, Oxford, UK, Elsevier, 2007.

[23] A. W. Westerberg. User Guide on Process Integration for the Efficient Use of Energy. : Linnhoff B., Townsend D. W., Boland D., Hewitt, G. F., Thomas B. E. A., Guy A. R. and Marsland R. H., Institution of Chemical Engineers, Geo E. Davis B, Chem. Eng. Sci., 39, 619-20 (1984). DOI: http://dx.doi.org/10.1016/0009-2509(84)80063-9. 
